\title{
A Study to Evaluate the Effectiveness of Aloe Vera Gel on Pain Perception among Patients with Osteoarthritis at Selected Communities in Kanyakumari District
}

\author{
Bijilin Reeni. D ${ }^{1}$, George Joe Kumar. A $^{2}$ \\ ${ }^{1}$ Assistant Professor, E. S College of Nursing, Villupuram \\ ${ }^{2}$ Professor, St. Xaviers Catholic College of Nursing, Nagercoil
}

Corresponding Author: Bijilin Reeni. D

\begin{abstract}
Aim: to evaluate the effectiveness of Aloe Vera gel on pain perception among patients with osteoarthritis in selected communities at Kanyakumari district. Objectives: (i) To assess and compare the pre-test and post-test level of pain perception among patients with osteoarthritis in experimental and control group. (ii) To evaluate the effectiveness of Aloe Vera gel on level of pain perception among patients with osteoarthritis in experimental group. (iii) To find out the association between the post-test level of pain perception among patients with osteoarthritis in experimental group and control group with the selected demographic variables. A Quasi experimental, non-equivalent, pre test and post test control group design was adopted. The convenience sampling technique was used to select 30 samples for experimental group and 30 samples for control group. OARSI (osteoarthritis research society international) questionnaire was used to assess the osteoarthritic pain. Aloe Vera gel was applied locally on painful areas for 28 consequent days and post test was conducted on $28^{\text {th }}$ day by using OARSI questionnaire. The data were gathered and analyzed by descriptive and inferential statistical method. The findings revealed that during pre test 20(67\%) of them had moderate pain, $10(33 \%)$ of them had mild pain. During post test $19(63 \%)$ of them were in mild pain, $11(37 \%)$ of them were in moderate pain. The mean score on level of pain perception among patients with osteoarthritis was 33.3 in pre test and 22 in post test. The estimated t' value was 8.99* which is significant at $\mathrm{p}<0.05$. It shows
\end{abstract}

that local application of Aloe Vera gel was effective in reducing the level of pain perception among osteoarthritis pain. Hence the research hypothesis $\mathrm{H}_{1}$ is retained. This study statistically proved the pain reducing effect of Aloe Vera gel on Osteoarthritic patients at 5\% significant level. The researcher concluded that Aloe Vera gel application is a non pharmacological, cost effective and very practicable measure to reduce the level of pain perception among patients with osteoarthritis.

Keywords: Aloe Vera gel, Pain perception, Osteoarthritis.

\section{INTRODUCTION}

A healthy person can work with efficiency to earn wealth. The man who is not having a good health spends a lot of money on medicines and doctors. It is necessary to take precautions for building up a good health. In human mind, it is natural that he/she should be free from illness, injury or pain.

A joint is that where two or more bones come together, like the knee, hip, elbow or shoulder. Joints are damaged by many types of injuries or diseases. Joint disorder is a general term describing any abnormal condition that involves any aspect of a joint. It is osteoarthritis or called as osteoarthrosis. It is a progressive degenerative joint disease characterized by a gradual loss of cartilage. 
The exact disease mechanism is unknown. The joints become deformed when the space between the joint surface is lost. Cartilage is a protein substance that serves as a "cushion" between the bones of the joints where there are tough and elastic tissues. Osteoarthritis is characterized by a loss of articular cartilage. Among the hundreds of different types of arthritis, osteoarthritis is the most common, affecting over 25 million people in the United States.

Osteoarthritis occurs more frequently in old age. It is particularly a universal problem, increasing with the age. Aged people are more risky to develop degenerative joint change. Before the age of 45 , osteoarthritis occurs more frequently in males and it occurs after 55 in females. In the United States, both the races are equally affected. A higher incidence of osteoarthritis exists in the Japanese population, while the South-African blacks, the East Indians, and the Southern Chinese have lower rates.

Osteoarthritis is the second most common rheumatological problem and is the most frequent joint disease prevailing $22 \%$ to $39 \%$ in India. It is the most common cause of locomotor disability in elders. Osteoarthritis represents a major cause of morbidity and disability, and a significant economic burden on patients and health care resources.

Aloe Vera contains antiinflammatory compounds that suppress the interleukin-1 that causes inflammation in the joints. It also reduces the pain alongside. This helps to prevent the development of osteoarthritis symptoms and speed up recovery. The gel of the Aloe Vera has to be obtained to use for a topical application. It is a common way of accessing the benefits of the plant. Fresh Aloe Vera gel or a mixture can be taken and applied upto three times in a day to soothe pain and promote healing. It is also effective when there is a skin injury with joint pain. By using this topical application continuously injury and pain will be healed completely.

\section{Objectives}

- To assess and compare the pre-test and post-test level of pain perception among patients with osteoarthritis in experimental and control group.

- To evaluate the effectiveness of Aloe Vera gel on level of pain perception among patients with osteoarthritis in experimental group.

- To find out the association between the post-test level of pain perception among patients with osteoarthritis in experimental group and control group with the selected demographic variables.

\section{Hypothesis}

H1- There will be a significant difference between pretest and post test level of pain perception among patients with osteoarthritis in experimental group and control group.

H2- There will be a significant association between post test level of pain perception among patients with osteoarthritis in experimental group and control group with the selected demographic variables.

\section{Literature Review}

Karen Jean (2010) from national institutes of health conducted a study on efficiency and effectiveness of Aloe vera at university of Maryland medical Centre. It was concluded that symptoms of Osteoarthritis such as pain can be relieved with the topical application of pure Aloe vera gel, according to the National Center for Complementary and Alternative Medicine. Osteoarthritis is the most common form of arthritis that typically strikes the hands, knees, hips, lower back and neck. Aloe vera gel acts as an antiinflammatory agent and also encourages speedy healing of the affected osteoarthritic joints and reduces pain ${ }^{[27]}$.

James Fulton, (2005) Newport Beach, California, stated that usage of topical Aloe in practice to speed wound healing and reduce osteoarthritic pain. Aloe vera was used to reduce severe joint and muscle pain associated with arthritis, as well as pain related to tendinitis and injuries. 
When applied directly to the area of pain, Aloe vera penetrates the skin to soothe the pain. Aloe vera contains anti-inflammatory agents such as, salicylates, natural steroids called phyto-steroids and vitamins A, B, C and $\mathrm{E}$ which act as powerful anti-oxidants. They act by mopping up high speed super oxides produced during the process of inflammation. Aloe Vera is also high in mineral content and enzyme reactions in the joint and allow the joint to heal quicker in patients with Osteoarthritis ${ }^{[25]}$.

\section{METHODOLOGY}

The purpose of the study was to evaluate the effectiveness of Aloe Vera gel on pain perception among patients with osteoarthritis in selected communities at Kanyakumari district.

A Quasi experimental, nonequivalent research design was carried out in this study. In this study convenience sampling technique was used to select 30 samples for experimental group and 30 samples for control group. The pre test and post test level of Osteoarthritic pain was assessed by using OARSI (Osteoarthritis Research Society International) questionnaire.

\section{RESULT}

Table 4.2.1: Frequency and percentage distribution of samples according pre test level of pain perception among patients with osteoarthritis in experimental and control group.

\begin{tabular}{|c|c|c|c|c|c|c|c|c|c|}
\hline \multirow{3}{*}{$\begin{array}{l}\text { Sl. } \\
\text { No }\end{array}$} & \multirow[t]{3}{*}{ Group } & \multicolumn{8}{|c|}{ Pre test level of pain perception } \\
\hline & & \multicolumn{2}{|c|}{ No Pain } & \multicolumn{2}{|c|}{ Mild Pain } & \multicolumn{2}{|c|}{ Moderate Pain } & \multicolumn{2}{|c|}{ Severe Pain } \\
\hline & & $\mathbf{f}$ & $\%$ & $\mathbf{f}$ & $\%$ & f & $\%$ & f & $\%$ \\
\hline 1 & Experimental group $(\mathrm{n}=30)$ & 0 & 0 & 10 & 33 & 20 & 67 & 0 & 0 \\
\hline 2 & Control group $(n=30)$ & 0 & 0 & 8 & 27 & 22 & 73 & 0 & 0 \\
\hline
\end{tabular}

Assessment of pre and post-test level of pain perception among patients with osteoarthritis in experimental and control group

Table 4.2.1 shows that, in experimental group, 20(67\%) of them had moderate pain, $10(33 \%)$ of them had mild pain, $0(0 \%)$ of them had no pain and $0(0 \%)$ of them had severe pain. In control group, $22(73 \%)$ of them had moderate pain, $8(27 \%)$ of them had mild pain, $0(0 \%)$ of them had no pain and $0(0 \%)$ of them had severe pain.

\section{Pretest level of pain perception}

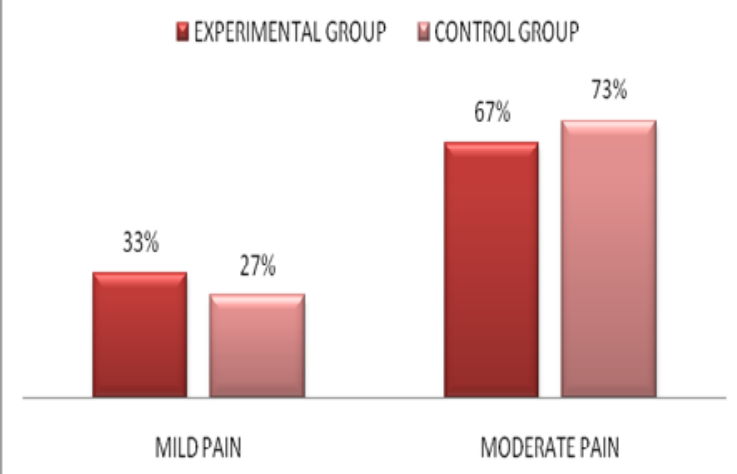

Figure 4.2.1: percentage distribution of samples according to pre test level of pain perception among patients with osteoarthritis in experimental and control group.

Table 4.2.2: Frequency and percentage distribution of samples according to the post test of level of pain perception among patients with osteoarthritis in experimental and control

\begin{tabular}{|c|c|c|c|c|c|c|c|c|c|}
\hline \multirow{2}{*}{$\begin{array}{c}\text { Sl. } \\
\text { No. }\end{array}$} & \multicolumn{9}{|c|}{ Post test level of pain perception } \\
\cline { 3 - 10 } & & No pain & Mild pain & Moderate pain & Severe pain \\
\cline { 3 - 10 } & $\mathbf{f}$ & $\mathbf{\%}$ & $\mathbf{f}$ & $\mathbf{\%}$ & $\mathbf{f}$ & $\mathbf{\%}$ & $\mathbf{f}$ & $\mathbf{\%}$ \\
\hline 1 & Experimental Group (n=30) & 0 & 0 & 19 & 63 & 11 & 37 & 0 & 0 \\
\hline 2 & Control group (n=30) & 0 & 0 & 6 & 20 & 24 & 80 & 0 & 0 \\
\hline
\end{tabular}

Table 4.2.2: shows that in experimental group, out of 30 samples, 19 $(63 \%)$ of them were in mild pain, $11(37 \%)$ of them were in moderate pain, $0(0 \%)$ of them had no pain and $0(0 \%)$ of them had severe pain. With regard to the level of pain perception in control group, out of 30 samples, 24(80\%) of them were in moderate pain, $6(20 \%)$ of them were in mild level of 
pain, $0(0 \%)$ of them had no pain and $0(0 \%)$ of them had severe pain.

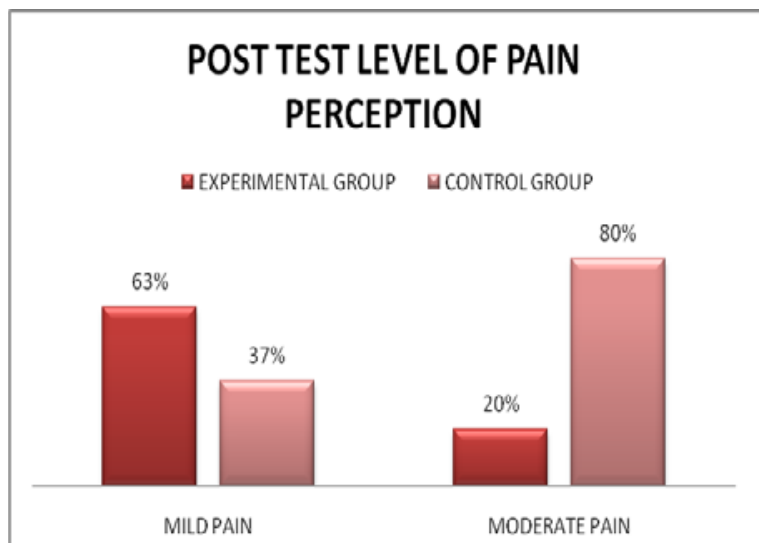

Figure 4.2.2: Percentage distribution of samples according pre test level of pain perception among patients with osteoarthritis in experimental and control group.

\section{Comparison of pre test and post test level of pain perception among patients with}

\section{osteoarthritis in experimental and control group}

Table 4.3 represents, the mean score on level of pain perception among patients with osteoarthritis in experimental group was 33.3 in pre test and 22 in post test. The estimated t' value was 8.99* which is significant at $\mathrm{p}<0.05$. It shows that local application of Aloe Vera gel was effective in reducing the level of pain perception among osteoarthritic pain. Hence the research hypothesis $\mathrm{H}_{1}$ is retained.

In control group the mean score on level of pain perception among patients with osteoarthritis was 32.6 in pre test and 32.8 in post test. The estimated t' value was 1.42 which is non significant at $\mathrm{p}<0.05$.

Table 4.3: Comparison of mean, SD, mean difference and paired't' value on pre test and post test level of pain perception among patients with osteoarthritis in experimental and control group.

\begin{tabular}{|}
\begin{tabular}{|c|l|c|c|c|c|c|}
\hline $\begin{array}{c}\text { Sl. } \\
\text { No. }\end{array}$ & \multicolumn{1}{|c|}{ Group } & Mean & SD & Mean Difference & df & Paired 't' value \\
\hline $\mathbf{1 .}$ & Experimental group (n=30) & & & & & \\
\hline & Pre test & 33.3 & 13.49 & 11.3 & 29 & $8.99 * \mathrm{~S}$ \\
& Post test & 22 & 9.825 & & & \\
\hline $\mathbf{2 .}$ & Control group (n=30) & & & & 29 & $1.42 \mathrm{NS}$ \\
\hline & Pre test & 32.6 & 12.77 & 0.2 & & \\
& Post test & 32.8 & 9.25 & & & \\
\hline
\end{tabular} \\
\hline
\end{tabular}

Association between the post test level of pain perception and their selected demographic variables in Experimental and Control Group

Table 4.6: Chi-Square test on the post test level of pain perception among patients with osteoarthritis in experimental and control group

\begin{tabular}{|c|l|c|c|c|c|c|c|}
\hline \multirow{2}{*}{ s.no. } & \multirow{2}{*}{ Demographic variables } & \multicolumn{3}{|c|}{ Experimental Group (n=30) } & \multicolumn{3}{c|}{ Control Group (n=30) } \\
\cline { 3 - 8 } & & df & Chi- Square & Table Value & df & Chi- Square & Table Value \\
\hline 1. & Age & 12 & 3.57 & 5.28 & 12 & 0.94 & 5.28 \\
\hline 2. & Sex & 4 & 1.17 & 5.99 & 4 & 3.75 & 5.99 \\
\hline 3. & occupation & 12 & 3.44 & 5.28 & 12 & 0.16 & 5.28 \\
\hline 4. & Educational status & 12 & 1.45 & 5.28 & 12 & 0.07 & 5.28 \\
\hline 5. & Marital status & 12 & 5.16 & 5.28 & 12 & 4.13 & 5.28 \\
\hline 6. & weight & 12 & 3.85 & 5.28 & 12 & 6.44 & 5.28 \\
\hline 7. & religion & 12 & 2.37 & 5.28 & 12 & 0.39 & 5.28 \\
\hline 8. & Duration of pain & 12 & 1.54 & 5.28 & 12 & 1.39 & 5.28 \\
\hline 9. & Activity inducing pain & 12 & 1.45 & 5.28 & 12 & 4.02 & 5.28 \\
\hline 10. & Action reducing pain & 12 & 1.10 & 5.28 & 12 & 4.28 & 5.28 \\
\hline 11. & Pain killers used for pain & 12 & 1.97 & 5.28 & 12 & 0.82 & 5.28 \\
\hline
\end{tabular}

Table 4.6 shows that there was no significant association of the post test level of of pain perception among patients with osteoarthritis in experimental and control group with their demographic variables such as age, sex, education, birth order, type of family, education of father, education of mother, monthly income of family, occupation of father, occupation of mother and religion at $\mathrm{p}<0.05$ level.

\section{DISCUSSION}

Frequency and percentage distribution of samples according to their demographic variables

Frequency and percentage distribution of demographic variables in the 
experimental group of patients diagnosed with osteoarthritis among 60 samples majority of them were in the age group of $9(30 \%)$ 41-50 years and 51-60 years, $20(67 \%)$ of the patients diagnosed with osteoarthritis were males, $12(40 \%)$ of them were skilled, $11(36.67 \%)$ of them are widows/widower, $9(30 \%)$ of them were at $61-70 \mathrm{~kg}, 10(33.33 \%)$ of them were Hindus, $11(36.67 \%)$ have pain for 1 year, $8(26.67 \%)$ have pain during rest time and during exercise, $14(46.67 \%)$ pain relieved by hot application, $9(30 \%)$ of them taken Diclofenac to relieve pain.

In the control group, majority $9(30 \%)$ of the patients diagnosed with osteoarthritis were in the age group of 41-50 years and $51-60$ years, $18(60 \%)$ of the patients diagnosed with osteoarthritis were males, $14(40 \%)$ of them were skilled workers, $12(40 \%)$ of them were married, $10(33.33 \%)$ of them were at $41-50 \mathrm{~kg}$, $11(36.67)$ of them were Christians, $11(36.67 \%)$ have pain below 6 months, $10(33.33 \%)$ have pain during rest time, $11(36.67 \%)$ pain relieved by hot application, 6(20\%) pain relieved by taking rest, $12(40 \%)$ of them taken Paracetamol to relieve pain.

The first objective was to assess and compare the pre test and posttest level of pain perception among patients with osteoarthritis in experimental group and control group.

The experimental group showed a mean value of 33.3 with standard deviation of 13.49 in pre test and the control group showed a mean value 32.6 with a standard deviation of 12.77 in pre- test. The calculated unpaired ' $\mathrm{t}$ ' test value was .206 which showed that there was a no significant difference between the pre test level of pain perception among the osteoarthritis in experimental and control group at $\mathrm{p}<0.05$ level.

The second objective was to evaluate the effectiveness of Aloe Vera gel on level of pain perception among patients with osteoarthritis with OARSI (Osteoarthritis research society international) pain assessment questionnaire in experimental group.

In the post test, the experimental group showed a mean value of 22with standard deviation of 9.825 and the control group showed a mean value of 32.8 with a standard deviation of 9.25 . The calculated unpaired ' $\mathrm{t}$ ' test value was 4.390 .

Which indicates a significant difference in the post test level of pain perception between experimental and control group. This revealed that the post test level of pain perception in experimental group was lower than that of the control group.

Hence the research hypothesis $\mathrm{RH}_{1}$ stated earlier that denotes "the mean post test level of pain perception among the osteoarthritis in experimental group will be lower than the mean post test level of pain perception in control group" was retained at $\mathrm{p}<0.05$ level. Hence hypothesis $\mathrm{H} 1$ is accepted.

The third objective was to associate the pre test and post test level of pain perception among patients with osteoarthritis in experimental group and control group with the selected demographic variable.

The analysis of post test level of pain perception of experimental group revealed that $24(80 \%)$ of them had mild level of pain and $6(20 \%)$ of the osteoarthritis patients had moderate level of pain perception.

The experimental group showed a mean value of 33.3 with standard deviation of 13.49 in pre test and a mean value of 22 with standard deviation of 9.825 in post test. The calculated paired ' $t$ 'test value was 8.99* which showed a significant difference between the pre and post test level of pain perception among experimental group of patients with osteoarthritis at $\mathrm{p}<0.05$ level.

Hence the research hypothesis $\mathrm{H}_{2}$ stated earlier that "the mean post test level of pain perception among the osteoarthritis patients in experimental group will be lower 
than the mean pre test level pain perception in experimental group" was retained at $\mathrm{p}<0.05$ level. Hence hypothesis $\mathrm{H} 2$ is accepted.

\section{CONCLUSION}

The findings revealed that during pre test $20(67 \%)$ of them had moderate pain, 10(33\%) of them had mild pain. During post test $19(63 \%)$ of them were in mild pain, $11(37 \%)$ of them were in moderate pain. The mean score on level of pain perception among patients with osteoarthritis was 33.3 in pre test and 22 in post test. The estimated t' value was $8.99 *$ which is significant at $p$ $<0.05$.

From the result of the study, it was concluded that local application of Aloe vera gel in wrist, knee, shoulder and hip osteoarthritis was effective in reducing pain. Therefore the investigator felt that, more importance should be given for local application of Aloe vera gel to reduce the pain perception of osteoarthritis patients.

Acknowledgement: None

\section{Conflict of Interest: None}

\section{Source of Funding: None}

Ethical Approval: Approved

\section{REFERENCES \\ BOOKS}

1. Agraham Apley, Louis Solomon. Concise system of Orthopedics and Fractures. Second edition. New Delhi: Jaypee Brothers Medical Publishers (P) Ltd; (1994). Page no-204

2. Barbara F. Weller, Baillier's nurse's dictionary, 24 ${ }^{\text {th }}$ Ed Philadelphia: Elsevier publications: (2008). Page no-30

3. Basavanthappa B. T. Medical Surgical

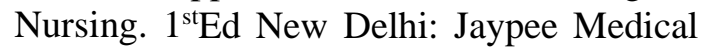
Publishers Private Limited; (2007). Page no205

4. Basavanthappa B. T. Research in Nursing.

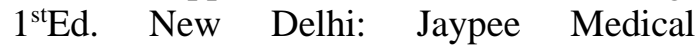
Publishers Private Limited; (2007). Page no105
5. Diana L. Anderson. Medical book of remedies- 50 ways to cope with arthritis. Louis weber publications; Page-13.

6. Hasnainwalji and Dr. Andrea Kingston. Arthritis and Rheumatism, A self help guide combining orthodox and complementary approaches to health. Norwich publisher's ltd; Page no-37.

7. John Crawford adams. Outline of orthopaedics. $8^{\text {th }}$ Ed. Churchill Livingstone publications; 2002. Page no-13.

8. Joyce M, Jane. Medical surgical nursing. $8^{\text {th }}$ edn.vol-1. Elsevier publication; page no-470

9. Kate lorig, James. F. Fries. The Arthritis help book, a tested self-management programme for coping with your Arthritis. California: Addison Wesley publications. Page no-113.

10. Lewis, Heitkemper, Dirksen, O’Brien, Bucher. Medical Surgical Nursing. $4^{\text {th }}$ edn. New Delhi: Mosby Publications; (2006).

11. Park. K, Text book of preventive and social medicine. $18^{\text {th }}$ Ed. Banarsidas publications; (2005).

12. Prof. Natarajan, prof. Mayil. V. Natarajan. Natarajans text book of orthopaedics and traumatology. $5^{\text {th }}$ edn.Chennai: Tik health care limited; Page no-7.

13. Polit F, Beck. Nursing Research. $3^{\text {rd }}$ edn.New Delhi: Lippincott William \&Wilkins Publications; 2008.

14. Priscilla lemone, Burke. Medical surgical nursing. $4^{\text {th }}$ edn. pearson publication.2008. page no-1449.

15. Richard. S.Panush, Nortin. M. HActivities of Daily Livinger, David. B. Hellmann, David. S. Pisetsky, Lee. S. Simon. Year book of rheumatology, Arthritis and Musculoskeletal disease. Mosby publications, 2000. page no-233.

16. Stanaka, C. Hamanishi. Advances in Osteoarthritis. Springer India publications; 2001 page no-15.

17. Suzanne C, Brenda bare.Medical surgical nursing. $10^{\text {th }}$ edn.Lippincott Williams and Wilkins;2004. Page no-1627.

\section{JOURNALS}

1. Agarwal. F. Aloe vera lowers blood glucose. Journal of Ethno pharmacology in India. (2007) page no: 28 (2): 215-220.

2. Amit A. Osteophytes in knee joint. India. Health action. June2009. Page no: 19-21.

3. Baby Joseph, Justin Raj, (2010). Pharmacological and non-pharmacological effect of Aloe vera an overview, 
Bijilin Reeni. D et.al. A study to evaluate the effectiveness of Aloe Vera gel on pain perception among patients with osteoarthritis at selected communities in Kanyakumari District

International Journal of pharmaceutical sciences review and research.12 (5); 200205.

4. Cowan, et al, (2010) British Journal of Community Nursing"; Oral Aloe Vera as a Treatment for Osteoarthritis: A Summary; D..; June.

5. Fulton James, (2010). Pharmacological and non-pharmacological effect of Aloe vera an overview, International Journal of pharmaceutical sciences review and research.12 (5); 200-205.

6. Hawker G. Osteoarthritic pain measure. Osteoarthritis research society international. Canada.2007 Dec. page no: 409-413.

7. Jean Karen c.Aloe vera a refreshing approach to natural health care.education news.issue9.page no: 1-4.

8. Uma R. Impact of disability on lifestyle of arthritic patients. India. Health action. June 2009.page no: 19-21.

\section{WEBSITES}

1. Woolf, Impact of Obesity and Knee Osteoarthritis on Morbidity and Mortality in Older

Americans,www.ncbi.nlm.nih.gov/pubmed/ 14710506

2. Nicks, right hip pain, http://www.buzzle.com/articles/right-hippain.html

3. Clegg.do.,Glucosamine, chondroitin sulfate, and the two in combination for painful knee Osteoarthritis,www.ncbi.nlm.nih.gov/pubm ed/16495392
4. Towheed, glucosamine on Osteoarthritis, www.jrheum.com/subscribers/07/09/1787.ht $\mathrm{ml}$

5. Perlman, massage therapy for Osteoarthritis, http://www.ncbi.nlm.nih.gov/pubmed/17159 021

6. Jordan, The use of conventional and complementary treatments for knee Osteoarthritis in the community, http://www.ncbi.nlm.nih.gov/pubmed/14623 948

7. Ettinger, aerobic exercises for Osteoarthritis, http://www.ncbi.nlm.nih.gov/pubmed/89802 06

8. Ruben titus, Aloe vera the magical plant, http://www.lulu.com/shop/dr-reubentitus/aloe-vera-the-magical-plant- amongstus/ebook/product-18948577.html

9. Heanders, Herbal supplements-Aloe vera uses and side effects, http://www.infobarrel.com/Herbal_Supplem ent_Aloe_Vera_Uses_and_Side_Effects

10. Karen hellesvig, pure Aloe vera gel uses, http://www.livestrong.com/article/103324pure- aloe-vera-gel-uses/

How to cite this article: Bijilin Reeni. D, George Joe Kumar. A. A study to evaluate the effectiveness of aloe vera gel on pain perception among patients with osteoarthritis at selected communities in Kanyakumari District. Galore International Journal of Applied Sciences \& Humanities. 2021; 5(4): 54-60. DOI: https://doi.org/10.52403/gijash.20211009 